\title{
Evaluation of Returns and Risks in the Forms of Garlic Market: Seed Versus in Natura
}

\author{
Dr. Luciano Bendlin ${ }^{1}$, Katia Adrieli Vichinheski ${ }^{2}$, Nazareth Pires Martins \\ Spautz $^{3}$,Viviane Maciel Scherer ${ }^{4}$ \\ ${ }^{1}$ Professor, Contestado of University, Brazil \\ ${ }^{2}$ Profa. Master student, Contestado of University, Brazil \\ ${ }^{3,4}$ Bel., Contestado of University, Brazil
}

\begin{abstract}
The garlic plant hortense Liliaceae, very used as spice, giving flavor to food and can be used in medicinal treatment. Its cultivation is an annual crop with all its processes since the preparation of the earth to their harvest. The context of this work was to evaluate their production, their use, their risks and seed and its consumption in natura. Their samplings were selected in Três Barras Town, Santa Catarina in 2014 harvest period. Among the seed (bulb) and in natura even with the risk of losses with fungal or bacterial their culture is considered a good harvest, because the climate is very favorable to its cultivation, detailing its costs of production and the difference between the crop seed and in natura. This study has used the Multi-index methodology to the analyzes and calculations for the comprehensive, such as: analysis of the $8.25 \%$ ROIA for garlic in natura and $7.44 \%$ in garlic seed on the initial investment. The cash flow based on monthly statements, involving expenditure on machinery, preparation of the land, among others. An initial investment of $R \$ 39.756,64$ for both harvests. Getting a VPL R\$63.188,55 for garlic in natura and $R \$ 54.303,99$ for garlic seed, its IBC considering the values of $2.59 \%$ for garlic in natura and 2.37 for garlic seed. The information about TMA/TRI were well satisfactory for the return of the harvest, as all cultures have risks, this harvest is approximately 50\% for both types being in the seed and in natura. The data was passed by the Crystal Ball for attesting and validation of calculations where is approved investment in agribusiness.
\end{abstract}

Keywords- Risk and Return. Garlic. Multi-index methodology.

\section{INTRODUCTION}

Agribusiness in Brazil has presented an evolution over the years, becoming a prosperous, safe and profitable activity, favorable for the diversified climate, being today the main locomotive of the Brazilian economy. It is more representative in the production of grains such as soy, corn, and in the sale of beef, pork and poultry. But the market has been expanding in other cultures, such as onions and garlic.

The production of garlic in Santa Catarina has been showing evolution and growth in the national production, being favored by relief, climate and land and social structure, making garlic a product of great socioeconomic importance for the state, making small and medium producers viable. ALHO, 2014).

However, the small farmer has no control of his costs in relation to the direct labor, with maintenance of the cultivation of his production and mainly with depreciation occurring in his machinery, where he indirectly affects his real cost in relation to the Production, and therefore the importance of obtaining a more targeted view of these issues, giving greater emphasis and obtaining the necessary data for risk assessment and feedback that helps decision making in order to minimize their losses and wastes.

This work gains importance due to the fact that it has a greater focus on the northern plateau of Santa Catarina, being a great help for the decision making mainly of the small farmers, where they can evaluate the best way of producing garlic in the region with a focus on profitability and Associated with the product.

The objective of this study is to analyze the production costs and expectations of return and risks associated with garlic agribusiness in the region of Planalto Norte Catarinense. Evaluate the risks and demonstrate the return of garlic production, applying the indicators Net Present Value (NPV), Annualized Net Present Value (NPV), Benefit / Cost Index (IBC), Return on Investment Added (ROIA), Internal Rate (TIR), Garlic Agribusiness Playback Period, using the multi-index methodology to obtain a better perception of the risks and the return of garlic production in this region, the data were confirmed through the Crystal software Ball.

This article is divided in five sections, beginning with introduction, followed by the theoretical reference where it deals with agribusiness, the garlic market, garlic cultivation, rural accounting and multi-index indicators. The third section deals with the methodological 
procedures in the elaboration of the research, section four is exposed the calculations and analyzes, and in the fifth section the final considerations.

\section{THEORETICAL FOUNDATION}

For the development of the theoretical reference of this article, it became necessary the bibliographical research, with definition of the concepts related to the study, such as agribusiness, garlic culture, rural accounting, multiindex methodology and its indicators and Monte Carlo simulation - Crystal Ball.

\subsection{AGRIBUSINESS}

Agribusiness in Brazil shows great credibility and growth after the consolidation of Brazil in the International scenario. Soil, climate, water and Brazilian relief are characteristics that favor agribusiness in the country. New technologies and processes have significantly changed the industry over the years, involving small and large companies.

Although these segments had their own functions, they have a very important link in the chain of production, becoming responsible for the link between the rural property and the final consumer, creating an integration of agriculture with commerce, industry, service providers and producer.

With this new scenario, the concept of primary agriculture no longer makes sense, and a new conception is necessary, which arises in the United States in the year 1957 through university professors the term agribusiness, defined as:

[...] the set of all operations and transactions involved from the production of agricultural inputs, from production operations in agricultural units to processing and distribution and consumption of 'in natura' or industrialized agricultural products (RUFINO, 1999 apud ARAÚJO, 2007, p.16).

The term spread throughout the world, being widespread in Brazil in the 80's and still being in English, the nomenclature Agribusiness began to be accepted in Brazil in the mid-90's, being used in books and newspapers.

The agribusiness presents some particularities that affect the production as:

a) Seasonality of Production - causes variations in the value of the commodity, between the harvesting periods between harvest, where it is necessary to improve the infrastructure for storage and conservation, with greater use of inputs;

b) Influences of biological factors - diseases and pests, which affect the cost of production, requiring adequate products, machinery and appropriate equipment to better preserve the quality of the product offered to the consumer;

c) Rapid perishability - after-harvest products have a fast cycle, which affects their useful life, so specific care is needed to extend the product life cycle.

The agribusiness productive chain acts in the analysis of the structure and functionality of the economic sectors of the activity. However, it must be emphasized that the productive chain is not limited to the process between the producer and the market, this affects other segments necessary for the development of agribusiness. The process can be classified into three segments, according to:

Classified into three segments, according to:

- Prior to Porteira: this segment is composed of suppliers of inputs and services necessary for agricultural production, such as machinery, implements, pesticides, fertilizers, correctives, seeds, water and energy. The services in this segment involve research and development institutions, financial institutions, and government agencies that operate in the sector. It should be noted that the components may vary according to the activity developed. In some cases, the number of suppliers may be reduced due to the specific characteristics of the activity.

- Within the gate: a segment constituted by the agricultural activity from the beginning of the activity of preparation of the inputs (soil, seeds, fertilizers, plantation) until obtaining the agricultural product ready for the industrialization process. In some activities, the process of industrialization still occurs within the gate, with the transformation of the agricultural product into industrialized product still in the agricultural property, this is the case of some dairy products, sugar, alcohol, sweets, among others. Although this industrial process is relatively common within the gate, in most agricultural activities the final product is traded in the primary form, without any type of value added.

- Porter: after harvest, agricultural products can be destined directly to the final consumer or to the processing industry. Products destined for final consumption are sold in bulk, or only a simple package, as in the case of some fruits, roots, grains and various vegetables, marketed in fairs or supermarkets that they buy directly from farmers. The products destined for processing receive the most diverse types of processing, in order to add value to the product offered to the final consumer. In addition to processing, it is the responsibility of the 
post-consumer segment to develop the logistics chain necessary for products to reach the consumer markets (SANTOS, SILVA, 2014).

\subsection{GARLIC}

Garlic, scientific name Allium sativum, a plant of Asian origin, belonging to the family Aliacea, can reach a height of $50 \mathrm{~cm}$ to $120 \mathrm{~cm}$, has an operational cycle around one hundred and thirty five days for cultivars precoce and one hundred and sixty Five days for late cultivars, and may present changes depending on the planting season, the planted variety and the production region.

The consumption is made by bulbs (head), composed of bulbilhos (teeth), and can be consumed raw, cooked or roasted, being used as seasonings, condiments and for medicinal purposes.

It can be verified that in the last twelve years it obtained a reduction in the planted area in $74 \%$ but its production increased in 34\%. In 1990 the area cultivated in Brazil was 17,535 hectares with production of 71 thousand tons and in 2012 was 10,064 hectares with 107 thousand tons (Revista Nosso Alho, 2014).

It is noticed that the production obtained increase due to the capacity of the producers to evaluate the factors that affect the productivity being the one of greater impact the quality of the garlic seed.

The production of garlic in Brazil, does not meet the consumption of the country, and with this needs to import. In the 2013/2014 harvest, Brazil's production accounted for $40 \%$ of garlic consumed by Brazilians, with the main garlic producing states of Minas Gerais, Goiás, Rio Grande do Sul, Santa Catarina and Bahia.

Garlic production in the country shows a productivity difference (tons per hectare), in 2012 the states with the highest production were Goiás (33\%), Santa Catarina (18\%), Minas Gerais (17\%) and Rio Grande do Sul \%).

The garlic has been used in addition to the kitchens, due to the benefits it produces, which has higher consumption. Garlic contains alliin and allicin components responsible for its odor and taste and its biological properties. The benefits are obtained by breaking the cell, by chewing or cooking, but frying decreases its properties.

It was found that Brazilian garlic is more beneficial than Chinese garlic, even though both have the same properties, but the Brazilian garlic conserves for a longer time the qualities of the existing nutrients. In addition, the Brazilian product has antioxidant in $70 \%$, contributing to prevent aging (Revista Nosso Alho, 2008).

The production of garlic goes through a critical period, because its profitability is low and its high cost, which does not allow the investment in the production, since the price practiced in the imports, mainly by China, is low.
However, in order to obtain greater investments in the crop, it is necessary that the influential factors be optimized, aiming at the greater profitability of the national production and thus reducing the dependence on imports.

\section{a) Cultivation of Garlic}

The garlic culture in Brazil began in the states of Minas Gerais and Goiás, where they produced white common garlic. Over the years the producers improved and began to grow purple garlic. The state of Santa Catarina was the pioneer in the cultivation of the noble purple garlic, specifically in the region of Curitibanos (Nosso Alho Magazine, 2008).

The Brazilian production presents variation over the years, with periods of growth and in others of reduction, nevertheless, it has presented a stability in the last years. This variation occurs due to the supply from the outside, which affects the value of the national merchandise, which ends up at certain moments discouraging the producers.

With the opening of the import market, garlic consumption in the country increased, but it destabilized some producers who ended up abandoning the crop and migrating to other crops. This occurred mainly in the region of Curitibanos and the Gaúcha Reaching the southern region of the country, which suffers from the competitiveness of Argentine garlic.

The alternative for the southern producer to remain in the market will be to invest in the cultivation of late varieties with high productive potential, with good quality seed and corrected soil.

\section{b) Climate}

The production of garlic in Brazil can be made in several states, except for hot or rainy regions. It is necessary to adapt to the variety and planting season respecting the climate of each region. The cultivation of garlic requires at the beginning or in the intermediary phase of temperatures between $0^{\circ} \mathrm{C}$ and $15^{\circ} \mathrm{C}$ (Portal Hortas), thus stimulating the formation of the bulbs.

Temperatures influence the development of the plant, being ideal temperatures in the period of formation of the bulb, and warmer in maturation, with periods of solar luminosity that will vary the time according to the cultivated variety.

\section{c) Alone}

Regarding the soil the garlic cultivation is not so demanding, being ideal soils light, drained and rich in organic material. However, if crop rotation is necessary, soil preparation varies according to the previous crop and should occur in advance of 35 to 45 days (Portal Hortas). Irrigation has its contribution, being necessary at the outset. 
Table.1: Production stages of Garlic

\begin{tabular}{|l|l|}
\hline Planting & $\begin{array}{l}\text { To obtain a good result it is necessary to make a good planting in an appropriate and cautious way. } \\
\text { The finest part of the bulb should be facing upwards, spacing between } 25 \text { and } 30 \mathrm{~cm} \text { between rows } \\
\text { and } 10 \mathrm{~cm} \text { between the plants (Portal Hortas). The spacing between lines and plants contributes to } \\
\text { the productivity of garlic. }\end{array}$ \\
\hline Harvest & $\begin{array}{l}\text { Harvest varies from sixteen to thirty-six weeks after planting depending on the variety planted, } \\
\text { planting season and region. The determination of the harvest period is done through visual methods } \\
\text { such as amount of green leaves, bulb formation. Harvesting can be done in two ways, either } \\
\text { manually or mechanically. }\end{array}$ \\
\hline Storage & $\begin{array}{l}\text { When manual harvesting takes place, it is necessary to pre-cure the production, where the plant } \\
\text { loses its excess water through sun exposure, which occurs between two to four days depending on } \\
\text { the climate, after it is collected and stored in a dry place and With good ventilation, care must be } \\
\text { taken at this stage so that the garlic is not beaten and the bulbs are not exposed to the sun. } \\
\text { Mechanical harvesting does not occur during the pre-cure period, where the machine is harvested } \\
\text { and lashed after production is stored in a cool, dry place with good ventilation, without the shape of } \\
\text { braids. }\end{array}$ \\
\hline $\begin{array}{l}\text { After the harvest and cure of the production the garlic goes through four phases to be ready for } \\
\text { commercialization, which are: } \\
\text { Cut } \square \text { where the garlic is cut, conditioned, and occurs the first selection of industrial garlic. Garlic } \\
\text { should be exposed to the sun or fans after cutting. } \\
\text { Classification } \square \text { garlic is classified by size by mechanical means, being careful not to affect the } \\
\text { quality of the bulbs. } \\
\text { Cleaning } \square \text { consists of removing the dirty outer tunics, and selecting by quality, removing the } \\
\text { bulbs with defects. } \\
\text { Packaging } \square \text { varies according to specification, garlic for consumption is commercially available in } \\
\text { bulk and in bulk in sacks. }\end{array}$ \\
\hline
\end{tabular}

Source: Adapted Portal Hortas (2016).

\subsection{RURAL ACCOUNTING}

Accounting can be applied generally or privately, while encompassing all branches is defined as general or financial accounting, in particular this is retained in the branch to be studied or applied to proper accounting. In this way, one has as defined Marion (2014).

1. Agricultural accounting $\square$ applied to agricultural enterprises;

2. Rural accounting $\square$ applied to rural enterprises;

3. Zootechnical Accounting $\square$ applied to companies that operate Zootechnics;

4. Livestock Accounting $\square$ applied to livestock enterprises;

5. "Agricultural Accounting" applied to agricultural enterprises;

6. Agribusiness Accounting $\square$ applied to agroindustrial companies.

\section{a) Agricultural activity}

The economic development of agricultural activity is influenced by market conditions and material resources, so the producer must have knowledge and thus make the decisions of which crop to invest, how much and how to produce, control the initial activity, analyze the results and compare with the Originally planned.
Agricultural activity is influenced by external factors such as climate, price of products, credit and financing policy, transportation and availability of labor and internal factors crop yields and combinations of productive activities, labor efficiency and Equipment and the administrator's personal conditions.

Revenue from the activity is normally concentrated during or shortly after harvest, being seasonal, with closure of the agricultural year soon after harvesting. In conducting the calculation of the result after harvest and commercialization, a better evaluation of the performance of the agricultural harvest is obtained, thus contributing to the decision-making and programming of the next agricultural year.

In case the company opts for several crops the agricultural year follows the cycle of the crop of greater economic representativeness, being carried out the evaluation of the harvest and commercialization of the main crop and evaluation of the other crops in formation.

With Law no. 7,450 / 85, making the Income Tax mandatory for all companies, making the fiscal year of the agricultural enterprise coincide with a calendar year, affecting rural accounting, as this does not normally coincide with the agricultural year. However, the 
agricultural year can be used for managerial purposes, where it will contribute to the evaluation of the activity.

\section{b) Rural activity in the new Civil Code}

With the amendment of the Civil Code that was in force in 2003, one can define the term entrepreneur as:

[...] who carries out professionally organized economic activity for the production or circulation of goods and services. Thus, the rural producer will be called a rural entrepreneur depending on the definition above, as long as he joins the trade board. Not signing up for the trade board, he will be an autonomous rural producer (MARION, 2014, p.7).

And if you consider the company:

[...] when people enter into a contract and reciprocally undertake to contribute goods and services to the exercise of economic activity and the sharing of results between them. Thus, the term business society replaces the previous term (commercial company). In this way, rural society (when there are two or more people together) is now seen as an entrepreneurial society (MARION, 2014 p.7).

With this, the entrepreneur whose rural activity is his main profession can exercise in the following legal forms: autonomous, individual entrepreneur, business society (MARION, 2014).

\section{A) Temporary crops}

In temporary culture, replanting after harvesting is required. These are short-lived crops, also known as annual crops, that is, every year it will be necessary to plant such crops as soybeans, corn, potatoes, onions, garlic.

The accounting is carried out in Current Assets in the same way as in the industry under the Inventory in Progress account. The costs will be accumulated in the culture sub-account in specific training of the temporary culture.

When only one crop is produced, the costs are direct, and when there is more than one crop it will be necessary to apportion indirect costs, proportional to each crop. The costs are seeds, fertilizers, seedlings, demarcations, labor, charges, electricity, social charges, fuel, insurance, professional services, insecticides, depreciation of tractors and other assets in the crop.

The agricultural activity has expenses and costs in the period, which has its differentiation where according to Marion (2014 p.15), it is considered:

Crop cost All expenses directly or indirectly identifiable with the crop (or product), such as seeds, fertilizers, labor (directly or indirectly), fuel, depreciation of machines and equipment used in the crop, agronomic and topographical services etc. .

Expenditures for the period are all expenditures that are not identifiable with the crop and are therefore not accumulated in the stock (temporary crops), but are appropriated as expenses for the period. Sales expenses (advertising, salesmen's commission ...), administrative expenses (directors' fees, office staff ...) and financial expenses (interest, bank fees ...).

The costs arising from the harvest will be recorded in the Culture account, after which the finished products will be downloaded and transferred to the new crop account, such as soybean, corn, potatoes, garlic and onion (MARION, 2014). Production costs can be classified as direct or indirect.

Expenses are expenses not identified with the crop, so it is not accumulated in the inventory and is appropriated with Expenses of the Period, they are expenses with sales, advertisements, administrative expenses, and financial expenses. These expenses are classified as Selling Expenses in the Operating Expenses group and not in the Cost of the Product, in the event that the agricultural product may be in stock, some prefer to count as accumulated cost of storage.

Depreciation, there are some difficulties to make the exact calculations of the equipment used in the crop, this item has gained space in recent times due to its use with its goal to improve productivity.

\subsection{MULTI-INDEX METHODOLOGY}

The multi-index methodology used for the decisionmaking process of a project with respect to its acceptance or rejection uses in addition to the indicators already mentioned above the Degree of Revenue Commitment (GCR), Risk Management and Business Risk, thus obtaining a better perception Of the risk offered by the project.

The essence of the Multi-index Methodology according to Souza and Clemente (2008: 124), consists of:

1. not incorporate the risk premium as a spread over the TMA;

2. to express the ROIA's profitability as an additional return, in addition to what would be earned by the application of capital in low-risk securities;

3. use the environmental analysis to deepen the assessment of the risks involved;

4. compare the expected gains with the perception of the risks of each project.

The degree of revenue impairment (GCR) is the proximity of the Operational Equilibrium (PEO) to the maximum capacity, where the operational break-even point is the 
minimum quantity to be sold in order to obtain settlement of production costs but without profit. The maximum capacity refers to the market's ability to sell.

The Management Risk associates with the degree of knowledge and competence of similar projects, being necessary the knowledge and experience accumulated on the productive process, commercialization process, distribution channels and in the condition of negotiations, aiding in periods of turbulence and unfavorable. It is necessary for the Management Risk assessment to make an assessment of the company's areas (SOUZA; CLEMENTE, 2008).

Business risk is associated with short-term and uncontrolled factors that end up affecting the project environment, being the degree of competition, barriers to entry and exit, trends in the economy and the sector of activity. It is possible to adopt evaluation adjustments, in relation to the factors and the techniques of analysis, being more effective in relation to the perception of the risks involved (SOUZA; CLEMENTE, 2008).

The investment is the disbursement aimed at generating a flow of future benefits, with prospects of receiving them.

The indicators generated help for the investment decision process through analysis. By analyzing the generated indicators, it becomes possible to follow the decisionmaking process of the investment. It is possible to ascertain viable alternatives and which are financially attractive, thus making it possible to decide between investing or refusing the project.

According to Souza and Clemente (2008, page 67) the indicators of analysis of investment projects can be subdivided into two groups:

a) Indicators of return on investment

The first index of profitability to be verified is the Net Present Value (NPV) that according to Souza and Clemente (2008, p.74),

The Net Present Value, as its name implies, is nothing more than the concentration of all expected values of a cash flow at date zero. To do so, the Company's Minimum Rate of Attraction (TMA) is used as the discount rate.

However, the NPV index is not enough for decision making, it is necessary to apply the others, initially no number is good or bad, but it should be compared with another reference, and the primary rule for NPV is as follows: NPV> $0 \square$ indicates that the project deserves further analysis (SOUZA; CLEMENTE, 2008).

For projects with long planning horizon, it is necessary to have a more approximate value for each period. With this, we can use average NPV, making it easier to reach a rational decision maker in terms of gain for the period than the accumulated gain in the long term.
Souza and Clemente (2008, page 77), describes the VPLa as:

The Annualized Net Present Value (VPLa), also known as Equivalent Uniform Annual Value (VAUE), is a variation of the Net Present Value Method. While the NPV concentrates all cash flow values at date zero, in the VPLa the cash flow representative of the investment project is transformed into a uniform series

Another index of profitability is the Benefit / Cost Index (IBC) that according to Souza and Clemente (2008, p. 78).

[...] is a measure of how much is expected to be earned per unit of invested capital. The hypothesis implicit in the IBC calculation is that resources released over the life of the project are reinvested at the rate of least attractiveness.

The benefit / cost ratio is the ratio of the expected benefit flow of a project and the expected flow of investments required to carry out the project (SOUZA \& CLEMENTE, 2008).

It can be calculated with the following formula:

$$
I B C=\frac{\text { Present value of the benefit stream }}{\text { Present value of the investment flow }}
$$

The Additional Return on Investment (ROIA) is the best profitability alternative, and the wealth generated by the project derives from the IBC equivalent rate of each project period.

a) Investment Risk Indicators

After verifying the profitability indexes of the project, it is time to look for risk indicators. The Internal Rate of Return (IRR) can be defined as: "rate that makes the Net Present Value (NPV) of a cash flow equal to zero" (SOUZA; CLEMENTE, 2008, p.81). It can be used to analyze the return dimension or the risk dimension.

By size return can be considered as upper limit for profitability of the project invested. The IRR can be considered representative of the project if the IRR and TMA values are the same. Regarding the risk dimension, the IRR is more relevant, being the upper limit for the variability of the TMA, due to the fact that the NPV is decreasing as the TMA approaches the IRR, where with the TMA equal to the IRR the project gain Is equal to zero (SOUZA; CLEMENTE, 2008).

The Payback Period is the "number of periods necessary for the flow of benefits to exceed the capital invested" (SOUZA; CLEMENTE, 2008, p.38).

As an indicator of importance in the investment decision process, it presents continuous and marked trends within the economy, since the invested capital must present a rapid return, to avoid the exclusion of investments in future projects. (SOUZA; CLEMENTE, 2008). 
These indicators have a better perception of the expected behavior between risk and return, where greater risks lead to an increase in the desired return (SOUZA; CLEMENTE, 2008).

The project must present a financial attractiveness, which results from the expected cash flow less the amount invested, in order to obtain the expected flow it will be necessary for the current value to be converted to future value. For this, it is necessary to have the value of the rate, known as the Minimum Attraction Rate.

The minimum attractiveness rate is the best low-risk rate available for the capital investment. If it is necessary for decision-making at least two alternatives, invest in the project or invest in the minimum rate of attractiveness.

The basis for establishing an MRA is the market interest rate. The interest rates that most impact the TMA are: Basic Financial Rate (TBF); Reference Rate (TR); Long-Term Interest Rate (TJLP) and Special System of Settlement and Custody Rate (SELIC) (SOUZA; CLEMENTE, 2008, page 71).

What is difficult to establish the TMA are the oscillations during the investment period of the rates that serve as floor and the ceiling for the TMA, being it possible that the rate of capture is greater than the rate of application.

However, even with the development of all the indicators, a very relevant analysis is necessary, as these can present different results, which makes it difficult to obtain an immediate and effective solution. It is necessary at the end with the indicators in hand to ascertain and identify the performance presented for the investment in question, and the impact on the profitability of the company (Bendlin, 2016).

\subsubsection{Monte Carlo - Crystal Ball}

The Monte Carlo method is a simulator whose central idea is the use of random samples with the objective of allowing the observation of the performance of a variable in a system or process, being an effective method in the solution of problems encountered in the development of the project In several sectors.

Because it is a method associated with risk management, it is possible to obtain an estimate for decision making by constructing an activity template model, which includes the development of appropriate formulas and equations, data collection, probability distribution Related to the input variables, definition of the form of data registration, and validation of the model.

After collecting the data, the variables can be modified to obtain various results, analyze the various scenarios presented and carry out the evaluation of the business plan. With the evaluation of the factors found through the method, it is possible to identify the factors of greater impact for activity both positively and negatively, which facilitates decision making for project implementation.

\section{RESEARCH METHODOLOGY}

The objective of this research is to analyze the costs of production and the expectations of return and risks associated with garlic agribusiness. The investments, production costs, profitability and risks inherent to this agribusiness were detailed.

The application was applied in the property of $\mathrm{Mr}$. Américo Yoshio Nagano in the locality of São João dos Cavalheiros, in the municipality of Três Barras, Planalto Norte Catarinense in 01 (a) hectare.

\subsection{CHARACTERIZATION OF THE RESEARCH}

According to Gil (2010), this research is classified as applied in relation to its nature, since it covers studies designed to solve problems identified within the scope of the societies in which it is being researched.

With regard to its objective, it is classified as descriptive, presenting the investments, costs and main activities necessary to the exploitation of the garlic culture, aiming to study the expectation of return and risk of such culture. This type of research ntends to describe the characteristics of a certain population or phenomenon or to establish relations among variables (GIL, 2010).

It is classified as a survey, since it is characterized by direct interrogation, requesting information from a significant group of people (GIL 2010). As for its periodicity is characterized as a cross-sectional study, because the considerations will be in a period of time.

As for the technical procedures of data collection, it is classified as documentary based on internal controls, since it used documents elaborated with diverse and specific purposes.

The data analysis is classified as quantitative in the case of a research of economic science, with data collection applied to tables, graphs, involving statistical procedures (GIL, 2010).

\subsection{COLLECTION, TREATMENT AND ANALYSIS OF THE DATA.}

Data collection was initially performed through the internal controls related to the garlic production process, such as the costs incurred with planting, which corresponds to the direct labor costs plus the social charges, the inputs used in the planting and in the course of production And maintenance costs.

The information was published in a spreadsheet with the help of the Excel software, where the indicators Net Present Value (NPV), Annual Net Present Value (NPV), Benefit / Cost Index (IBC), Return on Investment Added (ROIA) , Internal Rate of Return (IRR), Minimum 
Attraction Rate (TMA) and Investment Recovery Period (Playback).

Regarding the approach to the problem, it is classified as quantitative, since it sought to classify and analyze based on numbers, using resources and statistical techniques (Moresi, 2003).

The characterization was given to one hectare of garlic with the characteristics of productivity, cost structure, storage mechanisms and commercialization, in the locality of Campo São João dos Cavalheiros, in the municipality of Três Barras, Planalto Norte Catarinense.

\section{PRESENTATION OF RESULTS}

The present study identifies the production costs of garlic in natura and garlic seed. It initially covers the operational costs of labor and equipment for land preparation, planting and after-care and consumed inputs, which are measured for the production of 1 hectare of garlic in natura and 1 hectare of garlic seed.

For the survey of production and maintenance costs, mechanized and manual operations related to the production itself were segregated.

The mechanized operations were calculated using the tractor, based on the hourly cost, according to Marion (2014), plus depreciation and other inputs according to tables 1 .

Table.1: Cost of mechanized operations for garlic production / ha

\begin{tabular}{|c|c|c|c|c|}
\hline Mechanized Operations & & & & \\
\hline Description & Specification & $\begin{array}{l}\text { Unit value } \\
\qquad(\mathrm{R} \$)\end{array}$ & $\begin{array}{l}\text { Quantity } \\
\text { Hours }\end{array}$ & $\begin{array}{c}\text { Unproductive phase } \\
\text { Formation lot } 180 \\
\text { days }(\mathrm{R} \$)\end{array}$ \\
\hline \multicolumn{5}{|l|}{ Soil preparation } \\
\hline Gradation & $\begin{array}{l}\text { Trator Case } 165 \text { Maxxum + } \\
\text { Grade Aradora }\end{array}$ & 103,51 & 3,5 & 362,29 \\
\hline Ground unpacking & $\begin{array}{l}\text { Trator Case } 165 \text { Maxxum + } \\
\text { Subsolador Asa }\end{array}$ & 105,12 & 4 & 420,48 \\
\hline \multirow[t]{2}{*}{$\begin{array}{l}\text { Plant Survey and Planting } \\
\text { Fertilization }\end{array}$} & $\begin{array}{l}\text { Trator Case } 165 \text { Maxxum + } \\
\text { Enxada Rotativa }\end{array}$ & 104,18 & 8 & 833,47 \\
\hline & & & TOTAL & $1.616,24$ \\
\hline
\end{tabular}

Source: Authors (2016)

The manual operations were calculated from the use of working hours, based on the hourly cost man, according to Marion (2014), plus charges. The inputs applied in this step were also aggregated, according to tables 2.

Table.2: Cost of manual operations and inputs for garlic production / ha

\begin{tabular}{|c|c|c|c|c|}
\hline \multicolumn{5}{|c|}{ Operações Manuais } \\
\hline Description & Specification & $\begin{array}{l}\text { Unit value } \\
\qquad(\mathrm{R} \$)\end{array}$ & $\begin{array}{l}\text { Quantity } \\
\text { Hours }\end{array}$ & $\begin{array}{c}\text { Unproductive phase Formation } \\
\text { lot } 180 \text { days }(\mathrm{R} \$)\end{array}$ \\
\hline \multicolumn{5}{|l|}{ Implantation } \\
\hline \multirow[t]{2}{*}{ Planting } & Days / man & 46,96 & 44 & $2.066,40$ \\
\hline & SUBTOTAL & & & $2.066,40$ \\
\hline \multicolumn{5}{|l|}{ Fertilizers } \\
\hline \multirow[t]{2}{*}{ Fertilizer planting 09.25 .15} & $\mathrm{~kg}$ & 1,674 & 1000 & $1.674,00$ \\
\hline & SUBTOTAL & & & $1.674,00$ \\
\hline \multicolumn{5}{|l|}{ Others } \\
\hline \multirow[t]{3}{*}{ Seeds of Garlic } & $\mathrm{kg}$ & 40,00 & 860 & $34.400,00$ \\
\hline & SUBTOTAL & & & $34.400,00$ \\
\hline & TOTAL & & & $38.140,40$ \\
\hline
\end{tabular}

Source: Authors (2016)

For the maintenance of the garlic culture the mechanized operations used, such as sprays, cover fertilization, among others, are shown in table 3 . 
Table.3: Cost of mechanized operations for garlic

Mechanized operations

\begin{tabular}{llllr}
\hline Description & $\begin{array}{l}\text { Specification } \\
\text { Machine Hour }\end{array}$ & $\begin{array}{l}\text { Unit Value (R \$) } \\
\text { Per Hour }\end{array}$ & $\begin{array}{l}\text { Number of } \\
\text { hours }\end{array}$ & $\begin{array}{c}\text { Increasing production } \\
\text { Training in 180 days } \\
\text { Total (R \$) }\end{array}$ \\
\hline $\begin{array}{l}\text { Cultivation } \\
\text { Spraying }\end{array}$ & Landine Tractor + Sprayer & 85,96 & 522,86 \\
rrigation & I Equip.Irrigação Completo & 42,43 & 40,08 & $1.697,17$ \\
\hline SUBTOTAL & & & & $\mathbf{2 . 2 2 0 , 0 3}$ \\
\hline TOTAL & & & $\mathbf{2 . 2 2 0 , 0 3}$ \\
\hline
\end{tabular}

Source: Authors (2016)

Manual operations for the maintenance of garlic, such as thinning / thinning, harvesting and the inputs applied in this step, are shown in Tables 4, 5, 6 .

Table.4: Cost of manual operations for maintenance of garlic in natura / ha

\begin{tabular}{|c|c|c|c|c|}
\hline \multicolumn{5}{|l|}{ Manual Operations } \\
\hline Description & Specification & Unit Value ( $\mathrm{R} \$$ ) & $\begin{array}{l}\text { Number of } \\
\text { hours }\end{array}$ & $\begin{array}{l}\text { Increasing production } \\
\text { Training in } 180 \text { days } \\
\text { Total ( } \mathrm{R} \$ \text { ) }\end{array}$ \\
\hline \multicolumn{5}{|l|}{ Implantation } \\
\hline \multirow[t]{2}{*}{ Raleo / Roughing } & Days / man & 51,66 & 25,00 & $1.291,50$ \\
\hline & SUBTOTAL & & & $1.291,50$ \\
\hline \multicolumn{5}{|l|}{ Harvest } \\
\hline \multirow[t]{2}{*}{ Manual Harvesting } & Days / man & 51,66 & 29,00 & $1.498,14$ \\
\hline & SUBTOTAL & & & $1.498,14$ \\
\hline \multicolumn{5}{|l|}{ Fertilizers } \\
\hline Cloreto & $\mathrm{Kg}$ & 1,50 & 100,00 & 150,00 \\
\hline Nitrabor & $\mathrm{Kg}$ & 3,92 & 100,00 & 392,00 \\
\hline \multirow[t]{2}{*}{ Ureia } & $\mathrm{Kg}$ & 1,50 & 100,00 & 150,00 \\
\hline & SUBTOTAL & & & 692,00 \\
\hline
\end{tabular}

Source: Authors (2016)

Table.5: Cost of manual phytosanitary operations for garlic (Continua...)

\begin{tabular}{|c|c|c|c|c|c|}
\hline Description & & Specification & Unit Value ( $\mathrm{R} \$$ ) & $\begin{array}{l}\text { Number of } \\
\text { hours }\end{array}$ & $\begin{array}{l}\text { Increasing production } \\
\text { Training in } 180 \text { days } \\
\text { Total ( } \mathrm{R} \$ \text { ) }\end{array}$ \\
\hline & Fitossanitários & & & & \\
\hline Fertilizers & Mancozin & $\mathrm{Lt}$ & 50,00 & 1,00 & 50,00 \\
\hline Fertilizers & Microxisto Tek-F & $\mathrm{Lt}$ & 60,00 & 0,74 & 44,58 \\
\hline Fungicide & Academic & $\mathrm{Lt}$ & 19,00 & 4,50 & 85,50 \\
\hline Fungicide & Cabrio Top & $\mathrm{kg}$ & 59,60 & 8,00 & 476,80 \\
\hline Fungicide & Comet & $\mathrm{Lt}$ & 112,28 & 1,10 & 123,51 \\
\hline Fungicide & Echo WG & $\mathrm{kg}$ & 38,50 & 4,00 & 154,00 \\
\hline Fungicide & Galben - M & $\mathrm{kg}$ & 40,00 & 7,50 & 300,00 \\
\hline Fungicide & Nativo SC 300 & $\mathrm{Lt}$ & 76,50 & 2,00 & 153,00 \\
\hline Fungicide & Neoran & $\mathrm{kg}$ & 13,50 & 3,10 & 41,85 \\
\hline Fungicide & Porteiro & $\mathrm{Lt}$ & 117,72 & 1,00 & 117,72 \\
\hline Fungicide & Proplant & $\mathrm{Lt}$ & 104,00 & 1,00 & 104,00 \\
\hline Fungicide & Redshield 750 & $\mathrm{~kg}$ & 39,15 & 1,00 & 39,15 \\
\hline Fungicide & Rovral & $\mathrm{Lt}$ & 175,00 & 2,00 & 350,00 \\
\hline
\end{tabular}




\begin{tabular}{|c|c|c|c|c|c|}
\hline Fungicide & Stimo & $\mathrm{Lt}$ & 48,66 & 3,40 & 165,44 \\
\hline Fungicide & Support & $\mathrm{Lt}$ & 12,61 & 7,00 & 88,27 \\
\hline Fungicide & Vondozeb $800 \mathrm{WP}$ & $\mathrm{Lt}$ & 17,90 & 2,00 & 35,80 \\
\hline Fungicide & Zetanil & $\mathrm{Lt}$ & 32,90 & 4,50 & 148,05 \\
\hline Herbicide & Poquer & $\mathrm{Lt}$ & 88,56 & 0,90 & 79,70 \\
\hline Herbicide & Totril & $\mathrm{Lt}$ & 184,80 & 1,67 & 307,69 \\
\hline Herbicide & Abamectin & $\mathrm{Lt}$ & 38,00 & 0,50 & 19,00 \\
\hline Herbicide & Actara $250 \mathrm{WG}$ & $\mathrm{kg}$ & 225,00 & 0,10 & 22,50 \\
\hline Herbicide & Assist & $\mathrm{Lt}$ & 9,00 & 1,10 & 9,90 \\
\hline Herbicide & Capture 400 EC & $\mathrm{Lt}$ & 248,14 & 0,15 & 37,40 \\
\hline Herbicide & Cefanol & $\mathrm{kg}$ & 33,90 & 5,50 & 186,45 \\
\hline Herbicide & Engeo Pleno & $\mathrm{Lt}$ & 130,00 & 0,20 & 26,00 \\
\hline Herbicide & Kraft 36 EC & $\mathrm{Lt}$ & 67,90 & 1,50 & 101,85 \\
\hline Herbicide & Paradox & $\mathrm{Lt}$ & 24,00 & 2,00 & 48,00 \\
\hline Herbicide & Platinum NEO & $\mathrm{Lt}$ & 139,20 & 0,15 & 20,88 \\
\hline Herbicide & Premio 20 & $\mathrm{Lt}$ & 588,60 & 0,30 & 176,58 \\
\hline Herbicide & Produtor & $\mathrm{Lt}$ & 35,70 & 1,00 & 35,70 \\
\hline Herbicide & Sabre & $\mathrm{Lt}$ & 18,50 & 4,00 & 74,00 \\
\hline Herbicide & Talstar & $\mathrm{Lt}$ & 95,60 & 0,10 & 9,56 \\
\hline \multicolumn{5}{|c|}{ SUBTOTAL } & $3.632,89$ \\
\hline
\end{tabular}

Source: Authors (2016)

Table.6: Cost of manual operations for maintenance of garlic seed / ha

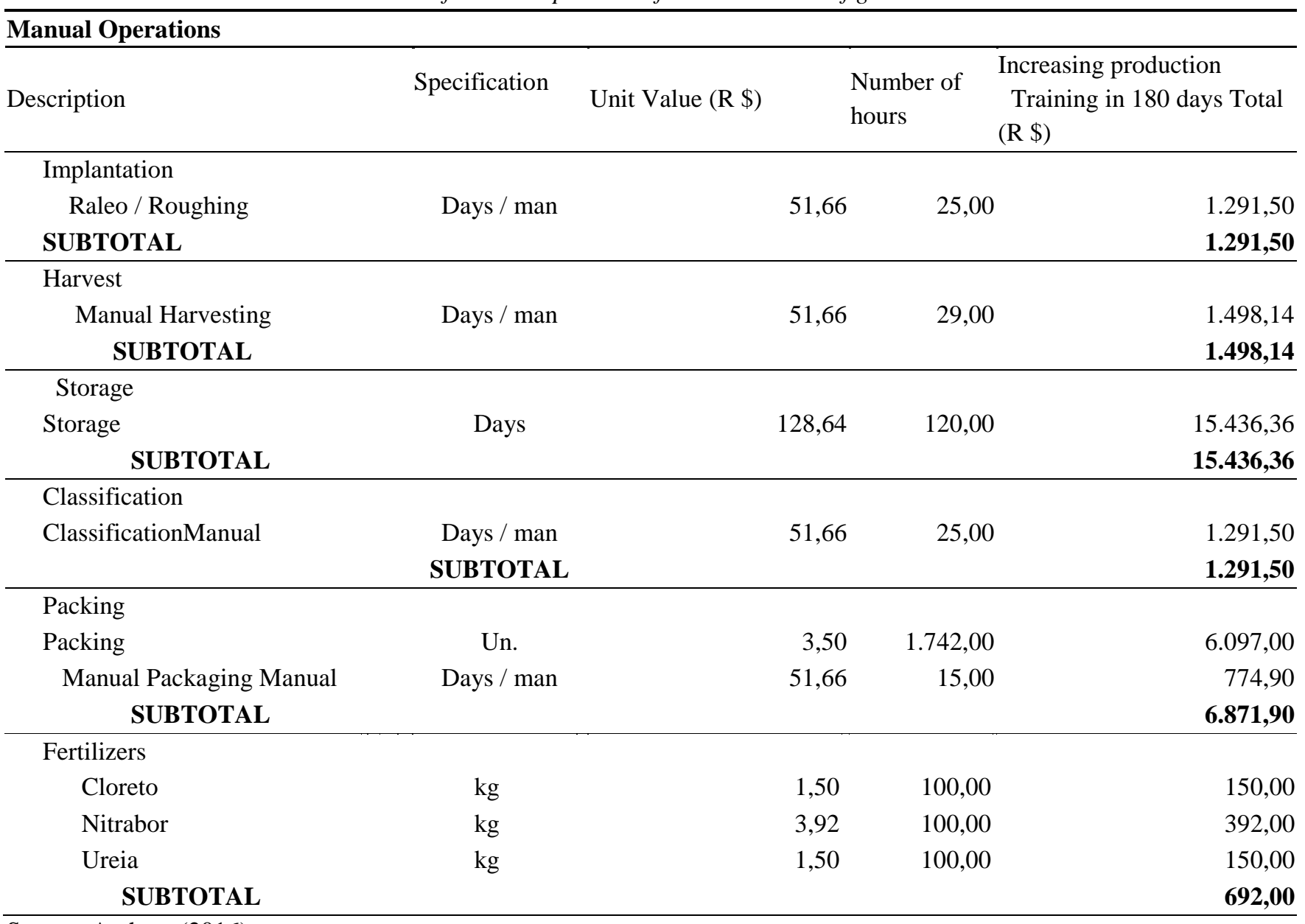

Source: Authors (2016) 
The production of garlic in natura and garlic seed presents in relation to the cost equal value until the harvesting process, having differentiation after harvest, as shown in tables 4 and 6 , in relation to the part of the pesticides the cost is the same as demonstrated In table 5.
The sale price practiced for the commercialization of garlic in natura and garlic seed are shown in table 7, on the value of the revenue occurs incidence of funrural $2.3 \%$.

Table.7: Practical Selling Price of Garlic

\begin{tabular}{|c|c|c|c|c|}
\hline \multicolumn{5}{|c|}{ Sale lot 180 days - 1 hectare - approximately 7,260 pounds } \\
\hline Description & Specification & $\begin{array}{l}\text { Unit value (R } \\
\$)\end{array}$ & Quantity kg & Total Value (R \$) \\
\hline \multirow[t]{2}{*}{ Garlic In Natura } & $\mathrm{Kg}$ & 12,00 & $7.260,00$ & $87.120,00$ \\
\hline & TOTAL & & & $87.120,00$ \\
\hline \multicolumn{5}{|c|}{$\begin{array}{l}\text { Sale lot } 270 \text { days - } 1 \text { hectare - approximately } 4.355 \text { kilos } \\
\end{array}$} \\
\hline \multirow[t]{2}{*}{ Garlic Seed } & $\mathrm{Kg}$ & 29,50 & $4.355,00$ & $128.472,50$ \\
\hline & TOTAL & & & $128.472,50$ \\
\hline
\end{tabular}

Source: Authors (2016)

The cash flow in table 8, characterized by garlic in natura, constructed from the information of the intensive system, shows the periods in which cash was disbursed, represents all the operational costs and the necessary inputs for the production. Within an initial disbursement of $\mathrm{R} \$$ $39,756.64$ for a crop. Be it garlic in natura and garlic seed.

Table.8: Statement of net cash flow from the commercialization of Garlic In Natura

\begin{tabular}{|c|c|c|c|c|}
\hline Months & INVESTMENT (R \$) & $\begin{array}{c}\text { GROSS REVENUE } \\
(\mathrm{R} \$)\end{array}$ & OPERATING COST (R \$) & CASH FLOW (R \$) \\
\hline 0 & $(39.756,64)$ & & & $(39.756,64)$ \\
\hline 1 & & & $(698,11)$ & $(698,11)$ \\
\hline 2 & & & $(876,42)$ & $(876,42)$ \\
\hline 3 & & & $(3.441,35)$ & $(3.441,35)$ \\
\hline 4 & & & $(1.903,29)$ & $(1.903,29)$ \\
\hline 5 & & & $(917,24)$ & $(917,24)$ \\
\hline 6 & $(39.756,64)$ & $87.120,00$ & $(3.501,90)$ & $43.861,46$ \\
\hline 7 & & & $(698,11)$ & $(698,11)$ \\
\hline 8 & & & $(876,42)$ & $(876,42)$ \\
\hline 9 & & & $(3.441,35)$ & $(3.441,35)$ \\
\hline 10 & & & $(1.903,29)$ & $(1.903,29)$ \\
\hline 11 & & & $(917,24)$ & $(917,24)$ \\
\hline 12 & & $87.120,00$ & $(3.501,90)$ & $83.618,10$ \\
\hline
\end{tabular}

Source: Authors (2016)

Table.9: Statement of net cash flow from the commercialization of Garlic Seed

\begin{tabular}{|c|c|c|c|c|}
\hline Months & INVESTMENT (R \$) & $\begin{array}{c}\text { GROSS REVENUE } \\
(\mathrm{R} \$) \\
\end{array}$ & OPERATING COST (R \$) & CASH FLOW (R \$) \\
\hline 0 & $(39.756,64)$ & & & $(39.756,64)$ \\
\hline 1 & & & $(698,11)$ & $(698,11)$ \\
\hline 2 & & & $(876,42)$ & $(876,42)$ \\
\hline 3 & & & $(3.441,35)$ & $(3.441,35)$ \\
\hline 4 & & & $(1.903,29)$ & $(1.903,29)$ \\
\hline 5 & & & $(917,24)$ & $(917,24)$ \\
\hline 6 & $(39.756,64)$ & & $(5.357,23)$ & $(45.113,87)$ \\
\hline 7 & & & $(3.160,98)$ & $(3.160,98)$ \\
\hline 8 & & & $(4.735,51)$ & $(4.735,51)$ \\
\hline 9 & & $128.472,50$ & $(18.418,71)$ & $110.053,79$ \\
\hline
\end{tabular}




\begin{tabular}{|c|c|c|c|}
\hline 10 & & $(1.903,29)$ & $(1.903,29)$ \\
\hline 11 & & $(917,24)$ & $(917,24)$ \\
\hline 12 & & $(5.357,23)$ & $(5.357,23)$ \\
\hline 13 & & $(3.859,09)$ & $(3.859,09)$ \\
\hline 14 & & $(3.859,09)$ & $(3.859,09)$ \\
\hline 15 & $128.472,50$ & $(14.977,36)$ & $113.495,14$ \\
\hline
\end{tabular}

Source: Authors (2016)

\subsection{INTERPRETATION OF RESULTS}

The risk and return indicators of the Multi-Index Methodology were prepared based on an initial investment of R \$39,756.64, from an MRA of $0.79 \%$ per month for a period of 06 months for fresh garlic and for 9 months For garlic seed, as presented in table 10.

Table.10: Marketing indicators for garlic in natura and garlic seed

Garlic In Natura Garlic Seed

\begin{tabular}{|c|c|c|c|}
\hline \multirow{5}{*}{ 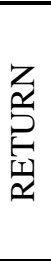 } & PRESENT VALUE & $102.945,19$ & $94.060,63$ \\
\hline & NET PRESENT VALUE & $63.188,55$ & $54.303,99$ \\
\hline & VALUE PRESENTED LIQUID ANNUALIZED & $5.541,47$ & $3.744,52$ \\
\hline & INDEX BENEFIT / COST (IBC) & 2,59 & 2,37 \\
\hline & ROIA / YEAR & $8,25 \%$ & $7,44 \%$ \\
\hline \multirow{4}{*}{$\frac{\mathscr{v}}{\widetilde{a}}$} & INTERNAL RETURN RATE (IRR) & $10,69 \%$ & $8,93 \%$ \\
\hline & TMA / TIR INDEX & 0,89 & 1,15 \\
\hline & RISK OF MANAGEMENT & 0,50 & 0,50 \\
\hline & RISK OF BUSINESS & 0,51 & 0,51 \\
\hline
\end{tabular}

Source: Authors (2016)

Regarding the return indicators, from a TAM of $0,79 \%$ am for the cultivation of garlic seed and garlic in natura, the expectation of recovering the investments made is confirmed, from the Present Value of R \$ 94,060, 63 for garlic seed and a present value of $\mathrm{R} \$ 102,945.19$ for garlic in natura, generating a Net Present Value of $\mathrm{R} \$$ 54,303.99 and $\mathrm{R} \$ 63,188.55$, respectively.

The IBC - Benefit / Cost Index, which is an indicator that measures the expectation of return for each unit of capital invested, a result of $\mathrm{R} \$ 2.37$ for each $\mathrm{R} \$ 1.00$ investment of garlic seed and of $\mathrm{R}$ \$2,59 for each $\mathrm{R}$ \$ 1.00 investment in garlic in natura.

The ROIA - Additional Return Due to Investment is estimated at $7.44 \%$ a.a for garlic seed and $8.25 \%$ for garlic in natura.
Regarding the risk indicators, the IRR - Internal rate of return found was $8.93 \%$ for garlic seed and $10.69 \%$ for garlic in natura. The TMA / TIR index found was 1.15 for garlic seed and 0.89 for garlic in natura.

In relation to the risk of management that is associated with the experiences and knowledge of the production and marketing process that the producer has on the subject, the same can be considered of 0.50 , due to the availability of private technical guidance published in this segment. Return and risk are two variables that go together in the investment world. The greater the possibilities of return the greater the risks involved, as shown in table 11 .

Table.11: - Management Risk

\begin{tabular}{l|c}
\hline \multicolumn{1}{c|c}{ Skills } & Perception \\
\hline Economic Aspects & 0,45 \\
\hline Industry Trends and Segment & 0,55 \\
\hline Production Process and Innovation & 0,50 \\
\hline Negotiation with stakeholders & 0,45 \\
\hline Positioning Strategy & 0,50 \\
\hline Average per area & 0,41 \\
\hline Perceived Management Risk & 0,50 \\
\hline
\end{tabular}

Source: Souza and Clemente (2012, Adapted) 
In relation to business risk, it is characterized to problems that may affect the project environment, enters the risk market and its possible threats that may occur during the process, such as the weather, if during the process was better favorable for The business succeed, where there are many variations can compromise the outcome of the business. The same can also be considered of 0.51 because it is related mainly to the climate, since the lack of rain can damage the production of the vegetables, as shown in table 12 .

Table.12: Business Risk

\begin{tabular}{l|c|c|c|c|c}
\hline \multicolumn{2}{c|}{ PEST } & \multicolumn{2}{c}{ 5 Porter Forces } & \multicolumn{2}{c}{ SWOT } \\
\hline \multicolumn{1}{c|}{ Aspect } & Perception * & Aspect & Perception * & Aspect & Perception * \\
\hline Legal policy & 0,30 & Starter & 0,55 & Weaknesses & 0,45 \\
\hline Economic & 0,50 & Substitutes & 0,50 & Threats & 0,65 \\
\hline Cultural partner & 0,45 & Providers & 0,60 & & \\
\hline Technological & 0,30 & Customers & 0,45 & & \\
\hline Demographic & 0,30 & Competitors & 0,65 & & 0,55 \\
\hline Average & 0,37 & Average & 0,55 & Average & \\
\hline
\end{tabular}

Source: Souza and Clemente (2012, Adapted)

\subsection{FEASIBILITY ANALYSIS BY MONTE CARLO SIMULATION}

In the simulation, the quantity of 7,260 kilograms of fresh garlic and 4,355 of garlic seed was considered as uncertain variables or input variables for the simulation, and their respective sale price in each situation, called assumptions.

As for the variable sale price, the probability density function was chosen, with a value of $\mathrm{R} \$ 12.00 / \mathrm{kg}$ for the commercialization of garlic in natura and $\mathrm{R} \$ 29.50$ / $\mathrm{kg}$ for Garlic seed values are averages of the value practiced in the market according to surveys carried out during the course of the study, characterizing as a continuous probability distribution.

For forecast variables, we chose the NPV (Net Present Value), ROIA (Additional Return Due to Investment).

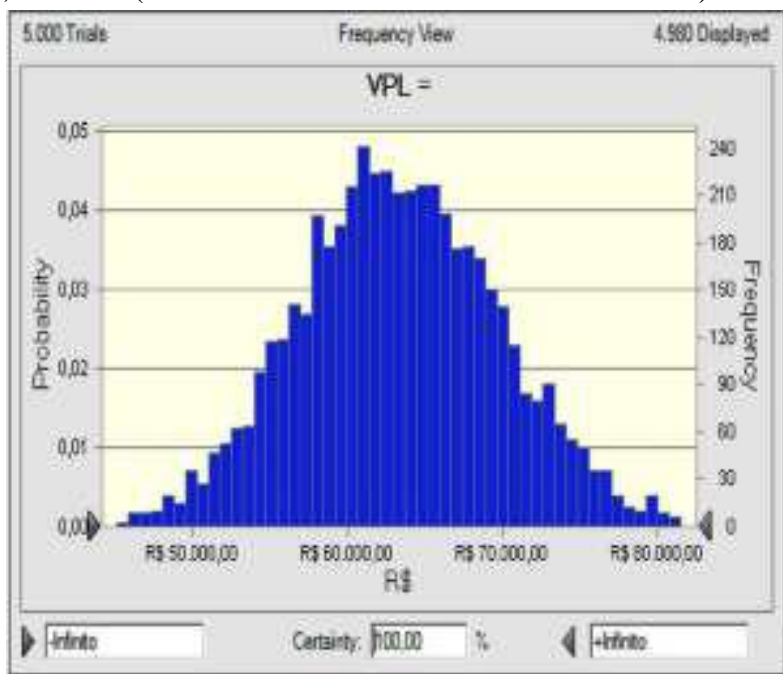

The number of replicates considered for the executed result was 5,000.

After the simulation was carried out, it was possible to obtain the frequency graphs with the minimum, mean and maximum values of the variables, median, variance and standard deviation, among other information.

Below you can see the graphs related to the selling price for garlic in natura and garlic seed. Figure 1 shows that the average for NPV (net present value) is R \$63,314.57 for garlic in natura and 54,510.95 for garlic seed, values very close to those found in the Multi-Index, which are $\mathrm{R}$ $\$ 63,188,55$ and $\mathrm{R} \$ 54,303.99$ respectively. The minimum value was $\mathrm{R} \$ 41,121.18$ for garlic in natura and 24,586.85 for garlic seed, and a maximum of $\mathrm{R} \$$ $85,587.99$ for garlic in natura and $88,522.71$ for garlic seed.

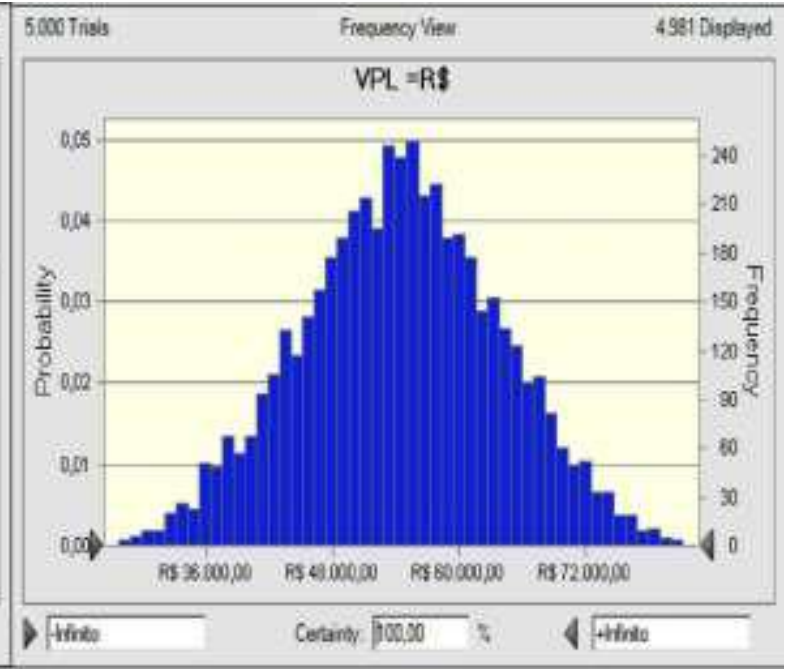

Fig.1: Frequency graph and statistics of the output variable NPV - Net Present Value Garlic In Natura and Garlic Seed Source: Authors (2016) 
Figure 2 shows that the average for ROIA (Additional Return Due to Investment) is $8.25 \%$ for garlic in natura and $7.42 \%$ for garlic seed, values very close to those found in the Multi-Index, which are $8,25 \%$ and $7.44 \%$ respectively. The minimum value was $6.10 \%$ for garlic in natura and $4.09 \%$ for garlic seed, and maximum of $10.04 \%$ for garlic in natura and $10.25 \%$ for garlic seed.
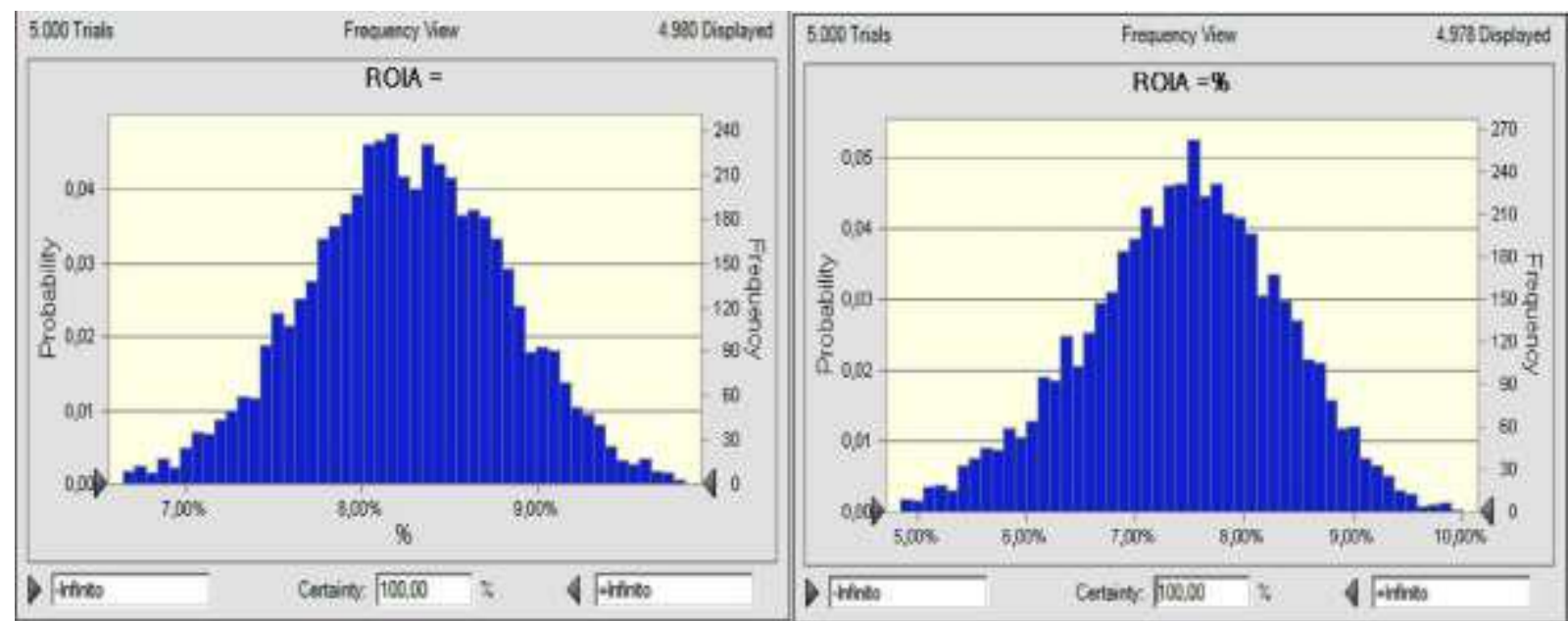

Fig.2: Frequency graph and output variable statistics ROIA - Additional Return from Investment Garlic In Natura and Garlic Seed

Source: Authors (2016)

\section{FINAL CONSIDERATIONS}

The purpose of this study was to analyze the expectations of return and the risks associated to the implementation of garlic cultivation, bringing the comparison between the commercialization of garlic in natura and garlic seed. The methodology used was the Multi-index, presented and discussed by Souza and Clemente (2008). Monte Carlo simulations were also carried out to verify and confirm the decision to invest in this agribusiness.

In the decision to invest in garlic cultivation there are two variables that determine the choice of garlic production for garlic consumption in natura or garlic seed production, productivity and marketing price.

The risk indicators for marketed garlic in natura are NPV of R $\$ 63,188.55$ and ROIA of $8.25 \%$, confirmed by Crystal Ball. When applied the competitive strategy in the production of garlic seed with expectation of return in 09 months, the impacts are of a NPV of R \$ 54,303.99 and a ROIA of $7.44 \%$.

The results show that the production of garlic in natura constitutes a more profitable activity, compared to the production of garlic seed.

Management and business risks were considered mediumsized, since public or private technical guidance is available for the agricultural segment, and such agribusiness is exposed to interference mainly from the climate.

The research concludes that the use of the multi-index methodology, its set of indicators for analysis, the evaluation of the return on investment and the associated risks improve the perception of the rural administrator, contributing with satisfactory results in its investment portfolio (Bendlin 2016).

The case study was carried out in a region in the interior of Santa Catarina that adopts garlic production, aiming to meet the maximum productivity; However, it is advisable to develop this study in other regions or small farms, under the possibility of obtaining different results, due to the possible variations, such as the inputs or the changes, that undergo market changes.

\section{REFERENCES}

[1] Association of Horti-Fruti Producers and Distributors of the State of São Paulo. Garlic. 2009. Available at: <http://www.aphortesp.com.br/alho.html>. Accessed on: 13 nov. 2014.

[2] BENDLIN, Luciano; SOUZA, A. ; VICHINHESKI3, K. A. . Methodology for the Construction of the Efficient Border For Selecting Investment Projects: A Multi-Index Approach. International Journal of Modern Engineering Research, v. 6, p. 8-22, 2016.

[3] BENDLIN, LUCIANO; SOUZA, A.; SENFF, C.O.; STAFIN, O. O.; PEDRO, J. J.. Production costs, return expectations and risks associated with eucalyptus plantation in the region of Planalto Norte Catarinense / Brazil .. Costs e @ gronegócio Online, v. 2, p. 2-33-33, 2016.

[4] National Association Of Garlic Producers. Brazilian garlic. Available at: 
<http://www.anapa.com.br/simples/?page_id=5>.

Accessed on: 06 Aug. 2014.

[5] Supply Centers Of The State Of Santa Catarina. Available

<http://www.ceasasc.com.br/cotacaodeprecosyg > Accessed on: 12 Sep 2015.

[6] GIL, Antonio Carlos. How to design research projects. 5.ed. São Paulo: Atlas, 2010.

[7] Lourenço, Joaquim Carlos. The evolution of Brazilian agribusiness in the current scenario. 29

Aug. 2008. Available at: <http://www.administradores.com.br/artigos/ economia-e-financas / a-evolucao-do-agribusinessbrasileiro-no-cenario-actual / 24824 / . Accessed on: 08 Oct. 2014.

[8] Lucini, Marco Antonio. Culture of garlic. Curitibanos: EPAGRI. Available at: <http://www.anapa.com.br/principal/images/stories/ documentos/Cultura_do_alho_no_sul.pdf $>$. Accessed on: 13 nov. 2014.

[9] Marion, José Carlos. Rural accounting. 14.ed. São Paulo: Atlas, 2014.

[10] Portal Hortas. How to Plant Garlic. Available at: <http://hortas.info/como-plantaralho>. Accessed on: 13 nov. 2014.

[11] Our Garlic Magazine. Brasília: ANAPA, ed. 1, ten. 2008. Available at: <http://www.anapa.com.br/simples/wpcontent/uploads/2013/04/1.pdf $>$. Accessed on: 20 Oct. 2014.

[12] Our Garlic Magazine. Brasília: ANAPA, n. 19, apr. 2014. Available at: <http://www.anapa.com.br/simples/wpcontent/uploads/2013/05/ Nosso_Alho_19_abril_2014-vers\% C3\% A3o-finalcompleto.pdf $>$. Accessed on: 30 Aug. 2014.

[13] Our Garlic Magazine. Brasília: ANAPA, n. 20 Aug. 2014. Available at: <http://www.anapa.com.br/simples/wpcontent/uploads/2014/ REVISTA_Nosso_Alho_n20_agosto_2014.pdf>. Accessed on: 24 jun. 2015.

[14] Rosamilha, Nelson. Monte Carlo Simulation Method. Jun.2012. Dimension:

[15] <Http://nelsonrosamilha.blogspot.com.br/2012/06/m etodo-de-simulacao-de-monte-carlo.html > Accessed on 18 Aug 2015.

[16] Santos, Daniel Ferreira dos; SANTOS, Renato da Costa dos; CATAPAN, Anderson. Administration of agribusiness in Brazil. 1.ed. Curitiba: CRV, 2014.

[17] Souza, Alceu; CLEMENT, Ademir. Financial decisions and investment analysis. São Paulo: Atlas, 2008. 